\title{
PARTISIPASI POLITIK PEMILIH PEMULA DALAM PEMILU PRESIDEN DAN WAKIL PRESIDEN TAHUN 2019 DI DESA KENDALSEWU-TARIK-SIDOARJO
}

\author{
Medyana Endria Novitasari ${ }^{1}$ Suhartono ${ }^{2}$ \\ Universitas PGRI Adi Buana Surabaya \\ Fakultas Keguruan dan Ilmu Pendidikan \\ Medyanaendria26@gmail.com¹ Suhartono@unipasby.ac.id ${ }^{2}$
}

\begin{abstract}
This research was underlied by the minimum education obtained by youths in the village. They were the beginner voters with low political education and dominated the number of political participation in the national level. This research aimed to know: 1) How was the political participation of beginner voters in the implementation of president and vice president election in Kendalsewu Village in 2019? 2) What were the factors that influence the participation of beginner voters in the implementation of president and vice president election in Kendalsewu Village in 2019? 3) What were the efforts done by KPPS to improve the political participation of beginner voters in the implementation of president and vice president election in Kendalsewu Village in the future?. This research used qualitative research method with data collection techniques were interview and documentation. Research results show that the political participation of beginner voters in Kendalsewu Village was 84,8\% or out of 132 beginner voters there were 112 or 12,8\% came to TPS and voted. The encouragement factors covered the awareness of the beginner voters, the motivation from parents, and Science and Technology. While the inhibition factors; there was no invitation (C6) and other bustles. The efforts done by KPPS in improving the political participation in the future were giving special socialization to beginner voters and political education.
\end{abstract}

Keywords: Political Participation, Beginner Voters, Presidential Election

\begin{abstract}
Abstrak
Landasan dari penelitian ini ialah kurangnya pengetahuan politik pemuda Desa Kendalsewu tentang pemilihan umum (Pemilu). kebanyakan dari mereka adalah pemilih pemula dengan pendidikan politik rendah dan mendominasi jumlah partisipasi politik di tingkat nasional. Tujuan dalam penelitian ini untuk mengetahui: 1) Bagaimana partisipasi politik pemilih pemula dalam pelaksanaan pemilihan presiden dan wakil presiden di Desa Kendalsewu pada tahun 2019? 2) Apa faktor yang mempengaruhi partisipasi pemilih pemula dalam pelaksanaan Pemilu presiden dan wakil presiden di Desa Kendalsewu pada tahun 2019? 3) Upaya apasajakah yang sudah dilakukan oleh KPPS untuk meningkatkan partisipasi politik pemilih pemula dalam pelaksanaan pemilihan presiden dan wakil presiden di Desa Kendalsewu di masa depan?. Metode dalam penelitian ini menggunakan metode penelitian kualitatif dengan teknik pengumpulan menggunakan wawancara dan dokumentasi. Hasil penelitian menunjukkan bahwa partisipasi politik pemilih pemula di Desa Kendalsewu adalah 84,8\% atau dari 132 pemilih pemula ada 112 atau 12,8\% yang datang ke TPS dan memberikan hak suara mereka. Faktor-faktor yang mendorong pemilih pemula berpartisipasi dalam pemilu diantaranya kesadaran pemilih pemula, motivasi dari orang tua,pendidikan dan Teknologi. Sedangkan faktor-faktor penghambatnya; tidak ada undangan (C6) dan adanya kesibukan pribadi. Upaya yang dilakukan KPPS dalam meningkatkan partisipasi politik adalah memberikan sosialisasi khusus kepada pemilih pemula dan memberikan pendidikan politik.

Kata kunci: Partisipasi Politik, Pemula, Pemilu Presiden
\end{abstract}




\section{PENDAHULUAN}

Pemilhan umum (PEMILU) merupakan sarana politik dan demokrasi di Indonesia, dengan diselenggarakan pemilu presiden mewujudkan apa yang telah dicita-citakan warga negara Indonesia yakni harapan agar kehidupan yang lebih baik, maju, sejahtera, adil dan makmur, warga negara Indonesia memiliki kebebasan dalam berpendapat dan berkehendak dalam memenuhi hak-haknya sebagai warga negara. Partisipasi politik wujud nyata keterlibatan seseorang atau warga negara untuk memilih pimpinan negara, dan secara langsung atau tidak langsung mempengaruhi kebijakan pemerintah/kebijakan negara (Budiardjo (dalam Hadiwijoyo 2012: 63)). jadi jelas partisipasi dalam pemilu di negara yang memiliki sistem demokrasi adalah hak warga negara.

Menurut pasal 1 ayat (22) UU No 10 tahun 2008, seorang pemilih pemula adalah warga negara Indonesia yang telah genap berusia 17 (tujuh belas) tahun atau lebih atau sudah pernah kawin, selanjutnya dipaparkan pada pasal 19 ayat (1 dan 2) UU No: 10 tahun 2008 bahwa pemilih yang mempunyai hak memilih adalah warga negara Indonesia yang didaftar oleh penyelenggara pemilu dalam daftar pemilih dan pada hari pemungutan suara telah genap berumur 17 (tujuh belas tahun) atau lebih atau sudah pernah kawin.

Dari kacamata demokrasi, sebenarnya pelaksanaan pemilu sangat baik bagi perkembangan demokrasi, akan tetapi pada praktiknya pemilu bergeser dari pesta demokrasi menjadi pesta politik yang penuh dengan persoalan hingga saat ini belum dirasakan bisa menjamin terwujudnya demokrasi yang hakiki. Masalah rendahnya partisipasi warga negara dalam pelaksanaan pemilu hingga bentuk perilaku pemilih yang tidak lazim menjadi sebuah masalah yang perlu dilakukan analisis yang mendalam, karena salah satu tolak ukur keberhasilan pelaksanaan pemilu dan demokrasi dapat diukur dari tingginya partisipasi pemilih.

Sisi lain pemilih pemula sebagai penerus bangsa perlu mendapatkan wawasan dan pengetahuan di bidang politik, termasuk pentingnya keikutsertaan mereka dalam kegiatan pemilu. Semua itu dilakukan untuk menekan angka Golongan Putih (golput) pada pelaksanaan pemilu. Golput ialah tindakan yang tidak bertanggungjawab atas pembangunan dan kelangsungan bangsa dan negara, karena mereka tidak memberikan apa yang seharusnya mereka berikan. Partisipasi dan keikutsertaan pemilih pemula juga berpengaruh dalam menentukan arah kebijakan di Indonesia ke depan. Dalam konteks tersebut, pemilih pemula harus paham apa makna demokrasi dalam sebuah negara dan bagaimana upaya dalam mencapainya, dengan begitu mereka dapat memposisikan dirinya sebagai warga negara yang mempunyai kewajiban menggunakan haknya sebagai warga negara. Pemilu dapat dikatakan berhasil apabila angka golput dibawah $20 \%$.

Saat ini orang Indonesia sedang diuji identitas dan ideologinya nasionalisme dengan semakin berkembangnya kasus intoleransi, kekerasan, terorisme, penistaan dan kasus-kasus lainnya. Itu euforia demokrasi setelah nilai-nilai hak asasi manusia diabaikan di era Orde Baru memicu keterbukaan kebebasan yang sepertinya tanpa terbatas sehingga memudarnya demokrasi nilai-nilai yang sesuai dengan budaya dan jiwa orang Indonesia. Upaya utama adalah bagaimana membangkitkan kembali semangat Indonesia keanekaragaman sebagai dasar kelahiran NKRI sehingga nilai-nilai toleransi, saling menghormati dan penghargaan menjadi kekuatan dalam mewujudkan Persatuan Indonesia. (Tetep:2018, https://www.atlantispress.com/proceedings/acec-18/25906011).

Dalam pendidikan politik dalam demokrasi tidak mengenal latar belakang masyarakat, semua memiliki hak yang sama dalam memilih dalam pelaksanaan pemilu. Pemilih dalam hal ini termasuk para pemilih pemula yang salah satunya para siswa yang masih duduk di bangku SMA/SMK,/MA sederajat yang menginjak usia 17 tahun ke atas dan mahasiswa yang 
menempuh pendidikan di perguruan tinggi sekitar umur 21 tahun, dan mereka yang sudah purna tugas dari anggota TNI/Kepolisian dan PNS.

Tinggi rendahnya partisipasi politik di negara berkembang ditentukan oleh 3 faktor: tingkat pendidikan, tingkat kehidupan ekonomi, fasilitas-fasilitas yang memungkinkan berlangsungnya partisipasi politik (Nazarudin Sjamsuddin, dkk (dalam Satrio 2016: 34)).

\section{KAJIAN PUSTAKA}

\section{Partisipasi Politik}

Partisipasi ialah ikut serta, turut ambil bagian dalam suatu kegiatan. Davis (dalam Satrio : 2018) partisipasi adalah suatu keterlibatan mental atau emosional kepada pencapaian tujuan dan ikut tanggung jawab didalamya. Arti partisipasi sebenarnya ialah setiap orang mengikuti sebuah perencanaan dan pelaksanaan kegiatan, dimana orang tersebut memiliki tanggung jawab yang sesuai dengan kewajibannya. Sedangkan arti partisipasi politik ialah aktivitas yang dilakukan oleh warga negara dengan tujuan untuk mempengaruhi pengambilan keputusan politik. Partisipasi politik dilakukan orang dalam posisinya sebagai warganegara, bukan politikus ataupun pegawai negeri. Sifat partisipasi politik adalah sukarela, bukan dimobilisasi oleh negara ataupun partai yang berkuasa (Hadiwijoyo 2012: 64). Cara mengetahui kualitas partisipasi politik warga negara dari bentuk-bentuk keterlibatan dalam berbagai tahap proses pembangunan yang terencana melalui perumusan tujuan sampai dengan penilaian dan pengambilan keputusan.

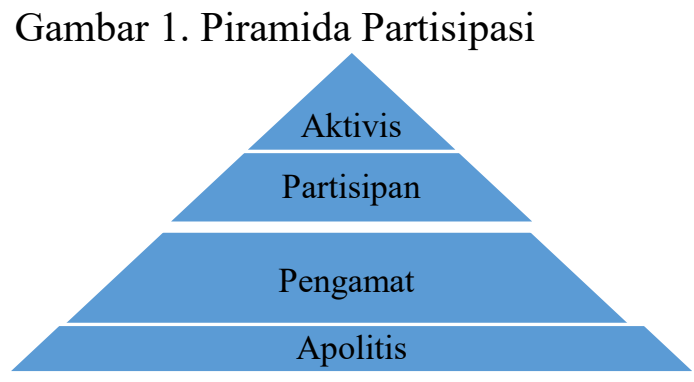

Sumber: Miriam Budiardjo (2008: 159)

Dalam buku Miriam Budiardjo (2008: 159) David F. Roth dan Frank L. Wilson membagi partisipasi menjadi beberapa bagian tingkatan, menggambarkan partisipasi politik dasar piramida partisipasi. Yakni membagi jenis partisipasi sesuai dengan frekuensi serta identitas. Roth dan Wilson mengutarakan pandangannya tentang piramida politik ini, menurutnya semakin tinggi intensitas dan derajat aktivitas politik seseorang maka semakin kecil kuantitas orang yang ada terlibat didalamnya. Aktivis yang paling atas dalam piramida partisipasi politik, mereka ialah pejabat dan pemimpin partai. Dinamai aktivis karena mereka fokus untuk mengurusi organisasi serta kegiatan politik. Lapisan kedua yaitu partisipan, partisipan ialah petugas kampanye dan anggota aktif, peran partisipan dalam kegiatan politik berada pada ukuran sedang, namun jumlah partisipan ini lebih banyak daripada jumlah aktivis. Kelompok ini lebih banyak dan juga mereka terlibat dalam kampanye, kegiatan sosial, aktif dalam parpol, serta kelompok kepentingan. Lapisan ketiga ialah pengamat kegiatan, mereka hanya ikut menghadapi rapat umum, diskusi politik, mengikuti perkembangan politik. Peran mereka dalam kegiatan politik tidak terlalu intensif, namun jumlah orang yang berada dalam posisi ini 
lebih banyak dari pada jumlah partisipan. Pengamat kegiatan ikut dalam kegiatan politik yang tidak banyak menyita waktu, tidak memaksa diri sendiri. Lapisan paling bawah ialah kelompok apolitis, kelompok ini sama sekali tidak peduli dengan aktivitas apapun yang memiliki hubungan dengan kegiatan politik. Tidak mau melibatkan diri dalam kegiatan politik.

\section{Pemilih Pemula}

Pemilih pemula ialah calon pemilih yang baru pertama kali menggunakan hak pilihnya. Pemilih pemula yaitu warga negara atau masyarakat yang harus memenuhi syarat untuk memilih. Masyarakat yang menjadi pemilih pemula antara lain: (1) Remaja yang berusia lebih dari 17 tahun, (2) sudah pernah kawin, (3) pensiunan anggota TNI/POLRI. Menurut pasal 1 ayat (22) UU No 10 tahun 2008, pemilih adalah warga negara Indonesia yang telah genap berumur 17 (tujuh belas) tahun atau lebih atau sudah/pernah kawin. Pemilih pemula merupakan objek dalam kegiatan politik, mereka yang masih memerlukan pembinaan dalam orientasi kearah pertumbuhan potensi dan kemampuannya, diharapkan kedepan dapat berperan dalam bidang politik. Pemilih pemula dalam hal ini termasuk para pemilih pemula salah satunya para siswa yang masih menempuh pendidikan tingkat SMA/SMK/MA sederajat yang berusia 17 tahun atau lebih, dan mahasiswa yang menempuh pendidikan di perguruan tinggi, dan mereka yang tidak lagi menjadi anggota atau pensiunan TNI/POLRI. Pemilih pemula masih perlu mendapatkan pembinaan dan pengarahan agar nantinya ikut serta dalam kegiatan politik secara optimal dan memiliki peran dalam kegiatan politik.

\section{METODE PENELITIAN}

Penelitian ini menerapkan pendekatan kualitatif, teknik pengumpulan data dilakukan secara triangulasi (gabungan), analisis data bersifat induktif, dan hasil penelitian kualitatif lebih menekankan makna dari pada generalisasi (Sugiyono, 2014:1). Instrumen utama dalam penelitian ini adalah peneliti. Penelitian kualitatif sebagai instrumen peneliti, menetapkan fokus penelitian, memilih informan yang menjadi sumber data, melakukan sumber data, memverifikasi data, serta membuat kesimpulan dalam bentuk temuan. Peneliti mendapatkan data dari KPPS, Perangkat Desa, Pemilih Pemula dan Masyarakat desa dengan menggunakan teknik wawancara dan dokumentasi. Data yang diperlukan adalah data tentang tingkat partisipasi politik pemilih pemula di Desa Kendalsewu Kecamatan Tarik Kabupaten Sidoarjo tahun 2019.

Analisis data yang digunakan yaitu analisis data interaktif dan berlangsung secara terus menerus sampai tuntas sesuai yang dikemukakan Miles dan Huberman. Aktivitas dalam analisis data tersebut yaitu reduksi data (data reduction), penyajian data (data display), penarikan kesimpulan (conclusion drawing/verification). Keabsahan data dalam penelitian ini, digunakan teknik triangulasi untuk memperoleh data. Terdapat 3 teknik triangulasi yakni triangulasi sumber, trianggulasi waktu, menggunakan bahan referensi.

\section{HASIL DAN PEMBAHASAN}

\section{Partisipasi Politik Pemilih Pemula di Desa Kendalsewu Kecamatan Tarik Kabupaten} Sidoarjo.

Pengguna Hak Pilih dan Data Pengunaan Surat Suara, pengguna hak pilih terbagi menjadi tiga bagian yaitu: Pemilih yang sudah terdaftar dalam DPT, Pemilih terdaftar dalam daftar pemilih pindahan (DPPh) pemilih ini menggunakan hak pilihnya di tempat yang berbeda dengan domisilinya, Pemilih terdaftar dalam daftar pemilih tetap tambahan. Pemilih ini sudah memenuhi persyaratan mengunakan hak pilihnya tetapi belum terdaftar dalam DPT. 


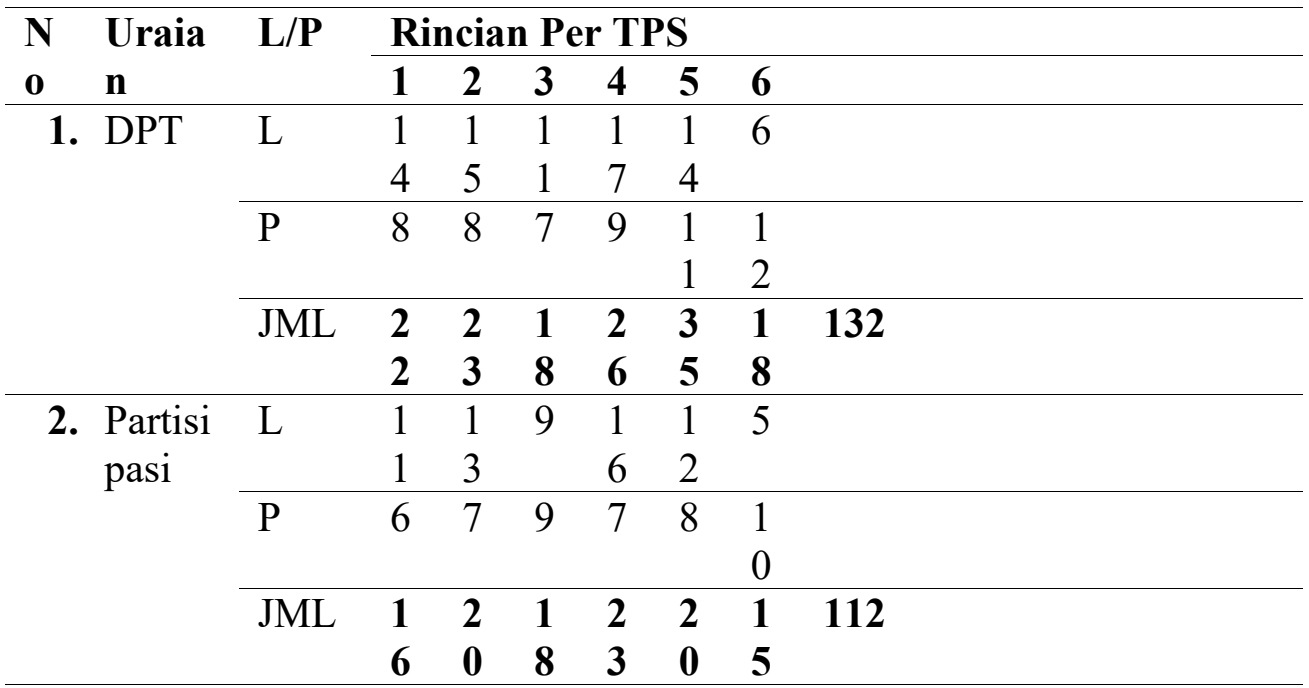

Sumber : Kantor Desa Kendalsewu

Tabel 2. Kriteria Tingkat Partisipasi Pemilih Pemula

\begin{tabular}{|c|c|c|l|}
\hline $\begin{array}{c}\text { Tingkat } \\
\text { Penguasaan }\end{array}$ & $\begin{array}{c}\text { Nilai } \\
\text { Huruf }\end{array}$ & Bobot & \multicolumn{1}{|c|}{ Predikat } \\
\hline $86 \%-100 \%$ & A & $\mathbf{4}$ & Sangat Baik \\
\hline $76 \%-85 \%$ & B & $\mathbf{3}$ & Baik \\
\hline $60 \%-75 \%$ & C & $\mathbf{2}$ & Cukup \\
\hline $55-59 \%$ & D & $\mathbf{1}$ & Kurang \\
\hline$\leq 54 \%$ & E & $\mathbf{0}$ & Kurang Sekali \\
\hline
\end{tabular}

(Purwanto 2013: 103)

Tingkat Partisipasi Pemilih Pemula $=\frac{112}{132} \times 100 \%=84,8 \%$

Desa Kendalsewu memiliki presentase predikat Sangat baik dengan presentase sebesar 84,8\% sehingga partisipasi pemilih pemula di Desa Kendalsewu dalam pemilihan Presiden dan Wakil Presiden memiliki tingkat partisipasi yang cukup tinggi.

\section{Faktor-faktor yang mempengaruhi partisipasi pemilih pemula} Faktor Pendorong:

a. Kesadaran Diri Pemilih Pemula

Partisipasi pemilih pemula dalam kegiatan pemilihan umum presiden dan wakil presiden di Desa Kendalsewu sangat aktif, hal tersebut disebabkan pemilih pemula memiliki rasa ingin tahu yang lebih besar untuk menggunakan hak pilihnya.

b. Motivasi Orang tua

Motivasi orang tua berpengaruh dalam kehadiran pemilih pemula untuk datang ke tempat pemungutan suara.

c. Perkembangan IPTEK

Ilmu pengetahuan dan teknologi yang terus berkembang hingga saat ini membuat kemuajuan pola pikir dan perilaku yang ada dalam masyarakat. Teknologi yang berkembang pesat pada saat ini juga mempengaruhi partisipasi pemilih pemula dalam kegiatan pemilihan umum. 


\section{Faktor Penghambat:}

a. Tidak mendapatkan $\mathrm{C} 6$

Tidak tercantumnya beberapa nama dalam daftar pemilih tetap yang pada akhirnya membuat pemilih tidak mendapatkan $\mathrm{C} 6$, hal tersebut menyebabkan pemilih yang seharusnya mendapatkan C6 menjadi kurang antusias dan tidak bersemangat hadir ke TPS untuk memberikan suaranya.

b. Adanya kesibukan

Kesibukan sebagian masyarakat juga menjadi faktor penghambat dalam pemilu, sehingga partisipasi menjadi berkurang. Urusan pribadi hingga pekerjaan menjadi salah satu penghambat sesorang untuk datang memberikan suaranya saat kegiatan pemilihan umum berlangsung.

\section{Upaya KPPS Untuk Meningkatkan Partisipasi Politik Pemilih Pemula}

Sosialisasi Kepada Pemilih Pemula, diadakan sosialisasi khusus bagi pemilih pemula dengan tujuan memberikan ilmu pengetahuan terkait pemilu. Pendidikan Politik, pendidikan politik diharapkan dapat meningkatkan pemahaman tentang hak, kewajiban dan tanggung jawab setiap warga negara. Menghias TPS dengan tema-tema semenarik mungkin, tujuannya memikat perhatian masyarakat khususnya pemilih pemula agar mau datang nyoblos ke TPS.

\section{Tingkat Partisipasi Politik Pemilih Pemula Desa Kendalsewu}

Desa Kendalsewu memiliki pemilih pemula yang berjumlah 132, sekitar 84,8\% (112) pemilih pemula mengikuti kegiatan pemilihan umum dan datang memberikan suaranya, sedangkan untuk pemilih pemula yang tidak hadir ke TPS berjumlah 15,2\% (20). Dalam Pemilihan Umum pada tanggal 17 April 2019 dalam rangka memilih Presiden dan Wakil Presiden. Dari data-data yang ada jumlah DPT di Desa Kendalsewu adalah 1.527, dapat dilihat tingkat partisipasi masyarakat desa cukup tinggi, presentase jumlah pemilih yaitu $85,46 \%$ (1305) dan sisanya tidak menggunakan hak pilih 14,53\% (222). Pemilih pemula merupakan salah satu faktor yang mempengaruhi tingkat partisipasi politik di Desa Kendalsewu karena rasa ingin tahu dan kesadaran yang tinggi dalam menggunakan hak pilihnya. Sebagian besar usia pemilih pemula kisaran 17 hingga 20 tahun. Mayoritas kehadiran pemilih pemula yang menggunakan hak pilihnya di TPS adalah pemlihih pemula yang masih menempuh pendidikan SMA Sederajat, dan mereka yang baru lulus SMA, sedangkan yang sudah bekerja dan menempuh pendidikan diluar kota sebagian dari lagi memilih tidak hadir memberikan suara dalam kegiatan pemilihan umum.

\section{Faktor yang Mempengaruhi Partisipasi Pemilih Pemula}

Kesadaran Diri Pemilih Pemula. Sebagaimana terdapat pemilih pemula yang baru memilih dan memberikan suaranya setelah mereka pensiun dari anggota TNI/POLRI. Partisipasi pemilih pemula di Desa Kendalsewu adalah karena rasa ingin tahu dan kesadaran yang tinggi untuk menggunakan hak pilihnya. Terdapat sekitar 30\% dari 10 informan yang telah diwawancarai serta di buktikan dengan pemilih pemula yang datang ke TPS, mereka memberikan suara karena merasa memiliki hak untuk memilih pemimpin yang bertanggung untuk 5 tahun ke depan.

\section{Motivasi Orang tua.}

Motivasi orang tua dari pemilih pemula tersebut memberikan motivasi agar pemilih pemula bersemangat dan antusias untuk datang memeberikan suaranya ke TPS. Pemilih pemula yang baru pertama memilih memerlukan arahan dari orang tua agar merasa memiliki rasa tanggung jawab untuk memberikan suaranya. motivasi dari orang tua menjadi suatu hal yang dapat meyakinkan pemilih pemulah bahwa suara mereka sangat menentukan kemajuan negara Indonesia dengan cara memilih pemimpin yang tepat. Perkembangan IPTEK. Ilmu pengetahuan dan teknologi yang terus berkembang masyarakat khususnya pemilih pemula 
lebih mengenal dan mengetahui proses pesta demokrasi ini secara transparan. Adanya perkembangan IPTEK maka kita dapat dengan mudah untuk mencari dan menggali informasi tentang pasangan yang sedang mencalonkan diri dalam pemilihan umum. Informasi tersebut tersedia dimana-mana dan dapat diakses kapan saja, dengan bekal ilmu yang memadai dan dan lingkungan yang memadai maka pemilih pemula dapat mengakses informasi dari berbagai media cetak, media elektronik dan internet tentang politik. Adapun Faktor penghambat pelaksanaan Pemilu Presdien dan wakil Presiden di Desa Kendalsewu ialah: Tidak mendapatkan C6. Surat undangan resmi dan surat pemberitahuan untuk menggunakan suara atau hak pilih di TPS. Dalam kegiatan pemilihan umum ini terdapat beberapa masyarakat yang namanya tidak tercantumnya dalam daftar pemilih tetap yang pada akhirnya membuat pemilih tidak mendapatkan $\mathrm{C} 6$, hal tersebut menyebabkan pemilih yang seharusnya mendapatkan C6 menjadi kurang antusias dan tidak bersemangat hadir ke TPS untuk memberikan suaranya. Adanya kesibukan. Kesibukan sebagian masyarakat juga menjadi faktor penghambat dalam pemilihan umum, sehingga partisipasi menjadi berkurang. Terdapat pemilih yang menyatakan ketidakhadirannya karena ada salah satu dari anggota keluarganya sakit dan harus menjaganya. Urusan pribadi menjadi salah satu penghambat seseorang untuk datang mmberikan suaranya saat kegiatan pemilihan umum berlangsung.

\section{Upaya KPPS Untuk Meningkatkan Partisipasi Politik Pemilih Pemula}

Sosialisasi Kepada Pemilih Pemula. Salah satu upaya yang dilakukan untuk meningkatkan partisipasi politik pemilih pemula dimasa yang akan datang yaitu panitia akan melakukan sosialisasi khusus pada pemilih pemula. Pendidikan Politik. Pemilih pemula dianggap tidak paham politik, maka dari itu mereka harus mendapatkan pendidikan politik kepada pemilih pemula agar mereka tau betapa pentingnya partisipasi mereka dalam pemilihan umum. Membuat tema pada setiap TPS. Salah satu cara untuk menarik perhatian masyarakat khususnya pemilih pemula agar antusias datang ke TPS yakni dengan cara menghias TPS semenarik mungkin.

\section{KESIMPULAN DAN SARAN}

Pertama, tingkat partisipasi politik pemilih pemula dalam pemilihan umum Presiden dan Wakil presiden tahun 2019 di Desa Kendalsewu berjumlah 112 dari 132 dari daftar pemilih tetap atau $84,8 \%$. Hal ini termasuk dalam kategori baik atau tinggi. Kedua, faktor yang mempengaruhi partisipasi politik pemilih pemula dalam pemilihan umum antara lain faktor pendorong dan faktor penghambat. Faktor pendorong meliputi: kesadaran diri dari pemilih pemula, motivasi dari orang tua, dan perkembangan IPTEK. Sedangkan, faktor penghambat antara lain yaitu tidak mendapatkan C6 dan adanya kesibukan lain. Ketiga, upaya yang dilakukan KPPS untuk meningkatkan partisipasi politik pemlih pemula di Desa Kendalsewu pada masa yang akan datang yaitu dengan cara memberikan sosialisasi khusus kepada pemilih pemula dan pendidikan politik.

Adapun saran yang bisa peneliti sampaikan adalah: Bagi Desa dan Pihak Panitia berdasarkan dari hasil penelitian dapat diketahui jumlah partisipasi politik pemilih pemula yang ada di Desa Kendalsewu. Hal tersebut dapat menjadi motivasi perangkat desa untuk memperbaiki dan mengadakan sosialisasi serta pendidikan politik kepada pemilih pemula dalam pemilihan umum pada masa yang akan datang. Bagi pemilih pemula pentingnya kesadaran partisipasi pemilih pemula untuk menggunakan hak suara. Adapun dorongan dari orang tua untuk memberi arahan pada anaknya tentang partisipasi politik khususnya pada pemilihan umum demi kemajuan negara menjadi lebih baik.

\section{DAFTAR PUSTAKA}


[1] Budiardjo, M. 2008. Dasar-Dasar Ilmu Politik. Jakarta: Gramedia Pustaka Utama

[2] Cholisin, dkk. 2007. Ilmu Kewarganegaraan. Jakarta: Universitas Terbuka.

[3] Hadiwijoyo, S. 2012. Negara, Demokrasi dan Civil Society.Yogyakarta: Graha Ilmu..

[4] Irene, S. 2011. Desentralisasi dan Partisipasi Masyarakat dalam Pendidikan. Yogyakarta: Pustaka Pelajar.

[5] Mochtar, H. 2011. Demokrasi \& Politik Lokal di Kota Santri. Malang: UB Press

[6] Moelong, Lexy. 2012. Metodologi Penelitian Kualitatif. Bandung: Remaja Rosdakarya.

[7] Panggut. Y. S. 2018. Partisipasi Politik Memilih Pemula dalam Pemilihan KepalaDesa di Desa Bungurasih Kecamatan Waru Kabupaten Sidoarjo Tahun 2016. Skripsi. Universitas PGRI Adi Buana Surabaya.

[8] Purwanto, N. 2013.Prinsip-Prinsip dan Teknik Evaluasi Pengajaran. Bandung : PT. Remaja Rosdakarya

[9] Sugiyono. 2014. Metode Penelitian Kuantitatif, Kualitatif, dan R\&D. Bandung: Alfabeta

[10] Tetep, 2018. Reorientation of Values of The Indonesian Diversity (ke-Bhineka-an Indonesia) to Reaffirming the National Identity. Advances in Social Science, Education and Humanities Research, volume 251. Annual Civic Education Conference (ACEC 2018). https://www.atlantis-press.com/proceedings/acec-18/25906011

[11]Undang-undang Nomor 10 Tahun 2008. Online, https://peraturan.bpk.go.id/Home/Details/39037/uu-no-10-tahun-2008, diunduh 19 September 2019 pukul 20.33 WIB 